\title{
Anti-citrullinated fibronectin antibodies in rheumatoid arthritis are associated with human leukocyte antigen-DRB1 shared epitope alleles
}

Joyce JBC van Beers ${ }^{1 *}$, Annemiek Willemze ${ }^{2}$, Judith Stammen-Vogelzangs ${ }^{1}$, Jan W Drijfhout ${ }^{3}$, René EM Toes ${ }^{2}$ and Ger J M Pruijn ${ }^{1}$

\begin{abstract}
Introduction: Fibronectin is one of the most abundant proteins present in the inflamed joint. Here, we characterized the citrullination of fibronectin in the joints of rheumatoid arthritis (RA) patients and studied the prevalence, epitope specificity and human leukocyte antigen (HLA) association of autoantibodies against citrullinated fibronectin in RA.
\end{abstract}

Methods: Citrullinated residues in fibronectin isolated from RA patient synovial fluid were identified by mass spectrometry. The corresponding citrullinated and non-citrullinated peptides were synthesized and used to analyze the presence of autoantibodies to these peptides in RA sera and sera from other diseases and healthy controls by ELISA. The data were compared with risk factors like shared epitope HLA alleles and smoking, and with clinical features.

Results: Five citrullinated residues were identified in fibronectin from RA synovial fluid. RA sera reacted in a citrulline-dependent manner with two out of four citrullinated fibronectin peptides, one of which contains two adjacent citrulline residues, in contrast to non-RA sera, which were not reactive. The most frequently recognized peptide (FN-Cit ${ }_{1035,1036}$, LTVGLTXXGQPRQY, in which $\times$ represents citrulline) was primarily targeted by anti-CCP (cyclic citrullinated peptide) 2-positive RA patients. Anti-FN-Cit ${ }_{1035,1036}$ autoantibodies were detected in 50\% of established anti-CCP2-positive RA patients and in 45\% of such patients from a early arthritis clinic. These antibodies appeared to be predominantly of the immunoglobulin $\mathrm{G}(\mathrm{lgG})$ isotype and to be associated with HLA shared epitope alleles (odds ratio $=2.11$ ).

Conclusions: Fibronectin in the inflamed synovia of RA patients can be citrullinated at least at five positions. Together with the flanking amino acids, three of these citrullinated residues comprise two epitopes recognized by RA autoantibodies. Anti-citrullinated fibronectin peptide antibodies are associated with HLA shared epitope alleles.

Keywords: rheumatoid arthritis, fibronectin, autoantigen, citrullination, ACPA

\section{Introduction}

Citrullination or deimination is a post-translational modification, in which a peptidylarginine is converted into a peptidylcitrulline by the enzyme family of peptidylarginine deiminases (PAD). Citrullinated proteins occur at inflamed sites in healthy individuals as well as

\footnotetext{
* Correspondence: J.vanbeers@ncmls.ru.nl

'Department of Biomolecular Chemistry, Institute for Molecules and Materials, Nijmegen Center for Molecular Life Sciences, Radboud University Nijmegen, P.O. Box 9101, 6500 HB Nijmegen, The Netherlands Full list of author information is available at the end of the article
}

in patients $[1,2]$. However, autoantibodies directed against citrullinated proteins (anti-citrullinated protein/ peptide antibodies, ACPA) are very specific for rheumatoid arthritis (RA). More than $70 \%$ of RA patients display ACPA, measured via the anti-CCP2 (cyclic citrullinated peptide 2) test, in their sera $[3,4]$. These antibodies are frequently present prior to disease onset and can predict the development of RA [5,6].

It is still not fully understood how RA originates and develops, although there is experimental evidence for several steps in this process [7]. Both genetic and 
environmental factors have been demonstrated to contribute to the development of the disease and ACPA production. The association of several $H L A-D R B 1$ alleles, which all share a highly conserved motif that is known as the shared epitope (SE), has already been reported many years ago $[8,9]$. Other genes that have been identified as risk factors for RA include PTPN22, the TRAF1-C5 locus, PADI4, STAT4, IRF5 and CTLA-4 [10-15]. Smoking has been demonstrated to be an environmental risk factor for RA and also for ACPA production in RA patients carrying SE alleles [16,17]. Other environmental risk factors that have been suggested to enhance the chance of developing RA include the exposure to mineral oil, diet restrictions and coffee intake [18-20]. However, these data still need confirmation.

Many citrullinated autoantigens (for example, fibrinogen, vimentin, $\alpha$-enolase) and ACPA directed towards these citrullinated proteins have been identified in RA [21-26]. Currently, the CCP2 test, which is based on a synthetic citrullinated peptide not related to proteins occurring in the inflamed joints of RA patients, is the gold standard [27-29] for ACPA testing. ACPA have recently been included in the new American College of Rheumatology/European League Against Rheumatism (ACR/EULAR) criteria for the classification of RA, because they are present early in the disease and can predict disease development and outcome $[5,30]$. The ACPA response in established RA patients is very heterogeneous and includes antibodies directed to many citrullinated proteins [31-33]. Because it has been suggested that ACPA play an important role in the development of the disease, it is important to learn more about the autoantigens that could be involved in the generation of ACPA [7]. Several citrullinated proteins occurring in the inflamed joints of RA patients have been identified previously. In part, their citrulline-containing epitopes have been mapped, particularly using synthetic peptides $[24,34]$ or material from cultured (non-synovial) cells (for example, HL-60 cells) [23]. It remains to be established whether these epitopes are relevant from a pathophysiological point of view. ACPA tests based upon citrullinated autoantigenic proteins may provide information on ACPA fine-specificities $[35,36]$ and may aid the differentiation between clinically distinct RA patient subgroups, although so far no correlations between ACPA fine-specificities and clinical phenotypes have been found [37-39].

One of the citrullinated proteins in inflamed synovial tissue identified previously is fibronectin (FN) $[40,41]$. FN is a glycoprotein, which can be a component of the extracellular matrix (insoluble form) or present in body fluids (soluble form). FN is involved in a variety of processes, such as wound healing, haemostasis, thrombosis and embryogenesis [42]. Several findings have been published linking (citrullinated) FN with RA. For example, citrullinated FN was found to be present in synovial tissue and synovial fluid (SF) of RA patients [41,43]. It has also been detected in pannus tissue and in immune complexes present in sera of RA patients $[44,45]$. FN might play a role in articular cartilage destruction, because it has been observed that FN fragments can stimulate the production of multiple mediators of matrix destruction, such as various cytokines and metalloproteinases $[46,47]$. However, the presence and characteristics of anti-citrullinated fibronectin antibodies in RA patients have not been studied yet.

In the current study, we have mapped citrullinated residues of FN isolated from the SF of RA patients and have used this information to investigate the $\mathrm{B}$-cell response to citrullinated $\mathrm{FN}$ in $\mathrm{RA}$.

\section{Materials and methods Patient material}

Synovial fluid (SF) samples from RA patients were a kind gift from Prof. Dr. B. Bozic (Department of Rheumatology, University Medical Center, Ljubljana, Slovenia). After SF samples were obtained by joint punctures (arthrocentesis), using needles with a diameter from 1.6 to $2.2 \mathrm{~mm}$, they were immediately centrifuged at 2,500 $\times$ g for 10 minutes at $4^{\circ} \mathrm{C}$ to separate insoluble and soluble components into pellet and supernatant fractions, respectively. Supernatant and pellet fractions were separately stored at $-80^{\circ} \mathrm{C}$ within two hours after taking the samples. The pellets were resuspended in EGTA lysis buffer (50 mM Tris- $\mathrm{HCl}, \mathrm{pH} 7.4,100 \mathrm{mM} \mathrm{KCl,} 1$ mM DTE, 0.1\% NP40, 10 mM EGTA, 0.5 mM PMSF and protease inhibitor cocktail). Supernatant fractions were diluted in five volumes of EGTA lysis buffer. After sonification, SDS was added (final concentration 2\%) and the fractions were heated and centrifuged at 12,000 $\times$ g. Supernatants were used for further analysis.

Sera from (established) rheumatoid arthritis (RA; $n=$ 110), systemic lupus erythematosus (SLE; $n=31$ ), and primary Sjőgren's syndrome (pSS; $n=31)$ patients were collected at the Department of Rheumatology of the University Medical Centre Nijmegen and the St. Maartenskliniek Nijmegen (The Netherlands). Sera from multiple sclerosis (MS; $n=31$ ) patients were collected at the MS Centrum Nijmegen (The Netherlands). Type 1 diabetes (T1D; $n=32$ ) sera were obtained from the Department of Immunohaematology and Blood Transfusion of the Leiden University Medical Centre (Leiden, The Netherlands). Early arthritis sera (EAC; $n=301$ ) were collected at the Department of Rheumatology of the Leiden University Medical Center (Leiden, The Netherlands) [48]. Tuberculosis (TB; $n=29$ ) sera were collected at Department of Internal Medicine, Tel Aviv Medical Center, Israel. Sera from healthy individuals 
(NS; $n=32$ ) were collected at the Sanquin Blood Bank in Nijmegen. Sera were stored at $-70^{\circ} \mathrm{C}$ until use.

ACPA levels in RA sera were measured using a commercial CCP2 ELISA kit (Euro-Diagnostica A.B., Malmo, Sweden).

These studies were approved by the local ethics committees; the need for patient consent was waived by the local ethics committees.

\section{Sample preparation and tandem mass spectrometry analysis}

Two SF samples from RA patients, the supernatant fraction of one and the pellet of the other, were depleted of albumin as described by Colantonio and coworkers [49], separated by SDS-PAGE and stained with colloidal Coomassie Brilliant Blue. Each lane of the gel, containing material from an individual SF sample, was sliced into 18 pieces and the polypeptides in these gel slices were digested after the addition of $20 \mu \mathrm{L}$ trypsin solution (15 $\mathrm{ng} / \mu \mathrm{L}$ trypsin in $25 \mathrm{mM} \mathrm{NH}_{4} \mathrm{HCO}_{3}$ and $5 \mathrm{mM}$ n-octylpyranoglucoside). Peptides were extracted by adding $50 \%$ acetonitril, $0.5 \%$ trifluoroacetic acid, $5 \mathrm{mM}$ n-octylpyranoglucoside followed by sonication. The protein digests resulting from each of the gel slices were separately analyzed by nano-LC-MS/MS (using a LTQ (linear trap quadrupole) Fourier Transform Ion Cyclotron Resonance mass spectrometer (LTQ FT, Thermo Scientific, Waltham, MA, USA)). Data were converted by BioWorks SEQUEST (Thermo Electron, Waltham, MA, USA) into a peak list, which allowed peptide identification with the Mascot Search database. Additionally, citrullination sites were checked manually. Mass deviations for precursor ions were set to $20 \mathrm{ppm}$ and deviations for the mass of fragment ions were set at $0.8 \mathrm{Da}$. Fixed modifications, besides citrullination, such as oxidation and methylation, were taken along during the analysis.

\section{Synthesis of citrullinated fibronectin peptides}

Peptides (Table 1) were synthesized by a solid-phase procedure using Fmoc chemistry as described previously
[50]. The peptides were at least $90 \%$ pure as deduced from their elution pattern on reversed phase HPLC.

\section{Enzyme-linked immunosorbent assay}

Enzyme-linked immunosorbent assays (ELISA) with fibronectin peptides were performed as described previously. Briefly, each well of a microtiter plate (Streptawell, Roche, Basel, Switzerland) was coated with $1 \mu \mathrm{g}$ biotinylated peptide in $0.1 \mathrm{~mL} \mathrm{PBS} / 0.1 \% \mathrm{BSA}$ overnight at $4{ }^{\circ} \mathrm{C}$. After washing three times with $\mathrm{PBST}_{0.1}$ (PBS, $0.1 \%$ Tween 20 ), wells were incubated with serum samples 100-fold diluted at in $\mathrm{PBST}_{0.05}$ (PBS, 0.05\% Tween 20) containing $1 \%$ BSA for one hour at $37^{\circ} \mathrm{C}$. After incubation, plates were washed three times with $\mathrm{PBST}_{0.1}$, followed by an incubation at $37^{\circ} \mathrm{C}$ with HRPconjugated goat anti-human IgG, IgM, IgA, kappa, lambda (DAKO, Glostrup, Denmark) or with either HRP-conjugated rabbit anti-human IgG, rabbit antihuman IgM or rabbit anti-human IgA (DAKO, Glostrup, Denmark). Bound antibodies were detected by the conversion of 3,3',5,5'-tetramethylbenzidine (TMB) and, after terminating the reaction by the addition of sulfuric acid, the absorbance was measured at $450 \mathrm{~nm}$. Cut-off values were determined as the mean value plus two times the standard deviation of normal human control sera.

ACPA fine specificity ELISA assays using peptides derived from citrullinated vimentin, fibrinogen and $\alpha$ enolase were performed as described previously $[39,51]$.

\section{Statistics}

A two-tailed unpaired t-test with a CI of 95\% was used to observe differences in reactivity between RA sera and non-RA sera with respect to the citrullinated peptides.

Univariate logistic regression analyses were performed for testing the association between several single risk factors (SE alleles as well as smoking) and anti-citrullinated fibronectin peptide antibodies in early arthritis patients. A Mann-Whitney U test was performed to address associations with the clinical phenotype (HAQ

Table 1 Sequences of synthetic fibronectin peptides

\begin{tabular}{|c|c|c|c|c|}
\hline $\begin{array}{c}\text { Peptide } \\
\text { name }\end{array}$ & Peptides identified in RA SF & Synthetic peptide ${ }^{a}$ & $\begin{array}{l}\text { Citrulline residues identified in } \\
\text { RA1 }\end{array}$ & $\begin{array}{l}\text { Citrulline residues identified in } \\
\text { RA2 }\end{array}$ \\
\hline $\mathrm{FN}-\mathrm{Cit}_{241}$ & DTRTSYXIGDTWSK, TSYXIGDTWSK & DTRTSYXIGDTWSZO & $x$ & $x$ \\
\hline $\mathrm{FN}-\operatorname{Arg}_{241}$ & & DTRTSYRIGDTWSZO & & \\
\hline $\mathrm{FN}^{-\mathrm{Cit}_{1035,1036}}$ & $\begin{array}{l}\text { LTVGLTXXGQPR, } \\
\text { AQITGYRLTVGLTXR }\end{array}$ & LTVGLTXXGQPRQYZO & $x$ & $x^{b}$ \\
\hline FN-Arg 1035,1036 & & LTVGLTRRGQPRQYZO & & \\
\hline FN-Cit 1162 & DGQEXDAPIVNK & LRDGQEXDAPIVNZO & $x$ & $x$ \\
\hline FN-Arg 1162 & & LRDGQERDAPIVNZO & & \\
\hline $\mathrm{FN}-\mathrm{Cit}_{2356}$ & RPGGEPSPEGTTGQSYNQYSQXYHQR & YNQYSQXYHQRTNZO & & $x$ \\
\hline $\mathrm{FN}-\operatorname{Arg}_{2356}$ & & YNQYSQRYHQRTNZO & & \\
\hline
\end{tabular}

${ }^{a} \mathrm{O}$, biotinylated lysine; $\mathrm{X}$, citrulline; $\mathrm{Z}$, aminohexanoic acid. ${ }^{\mathrm{b}}$ Only citrulline at position 1035 was identified 
(health assessment questionnaire) score, VAS (visual analog scale) score, swollen joint count and Ritchie index) of the early arthritis patients.

\section{Results}

Citrullinated fibronectin in synovial fluid samples of RA patients

To study the immune response to citrullinated FN in $\mathrm{RA}$, first the positions of the citrulline residues in FN isolated from the inflamed joints of RA patients were mapped. One supernatant fraction and one pellet fraction from SF samples obtained from two different RA patients (RA1 and RA2, respectively) were depleted of albumin by a differential precipitation procedure as described previously [49]. This resulted in two pellet fractions for each RA SF sample, which were separated by SDS-PAGE and stained with colloidal Coomassie Brilliant Blue (CBB) (Additional file 1: Figure S1). Subsequently, 18 equal slices, covering the largest polypeptides (slice number 1 , molecular weight $>$ 94,000 ) to the smallest polypeptides (slice number 18 , molecular weight $<14,000)$ were excised from the stained gel for both samples (Figure 1A). The polypeptides present in the slices were digested with trypsin and analyzed by LC-MS/MS. The identity of polypeptides and the positions of citrullinated residues were determined by database searches using Mascot (Version 2.1.03, Matrix Science Inc, Boston, MA, USA). To confirm the presence of citrullinated residues and to distinguish from deamidation of glutamine or asparagine residues, the peptide fragmentation patterns were inspected manually. One of the citrullinated proteins found in the SF of both patients was FN.

Figure 1B shows a schematic overview of all the FN peptide sequences obtained. This indicates that (fragments of) FN were present in material from many gel slices, indicative of a large variety of FN polypeptide lengths in SF samples. FN is a protein for which at least

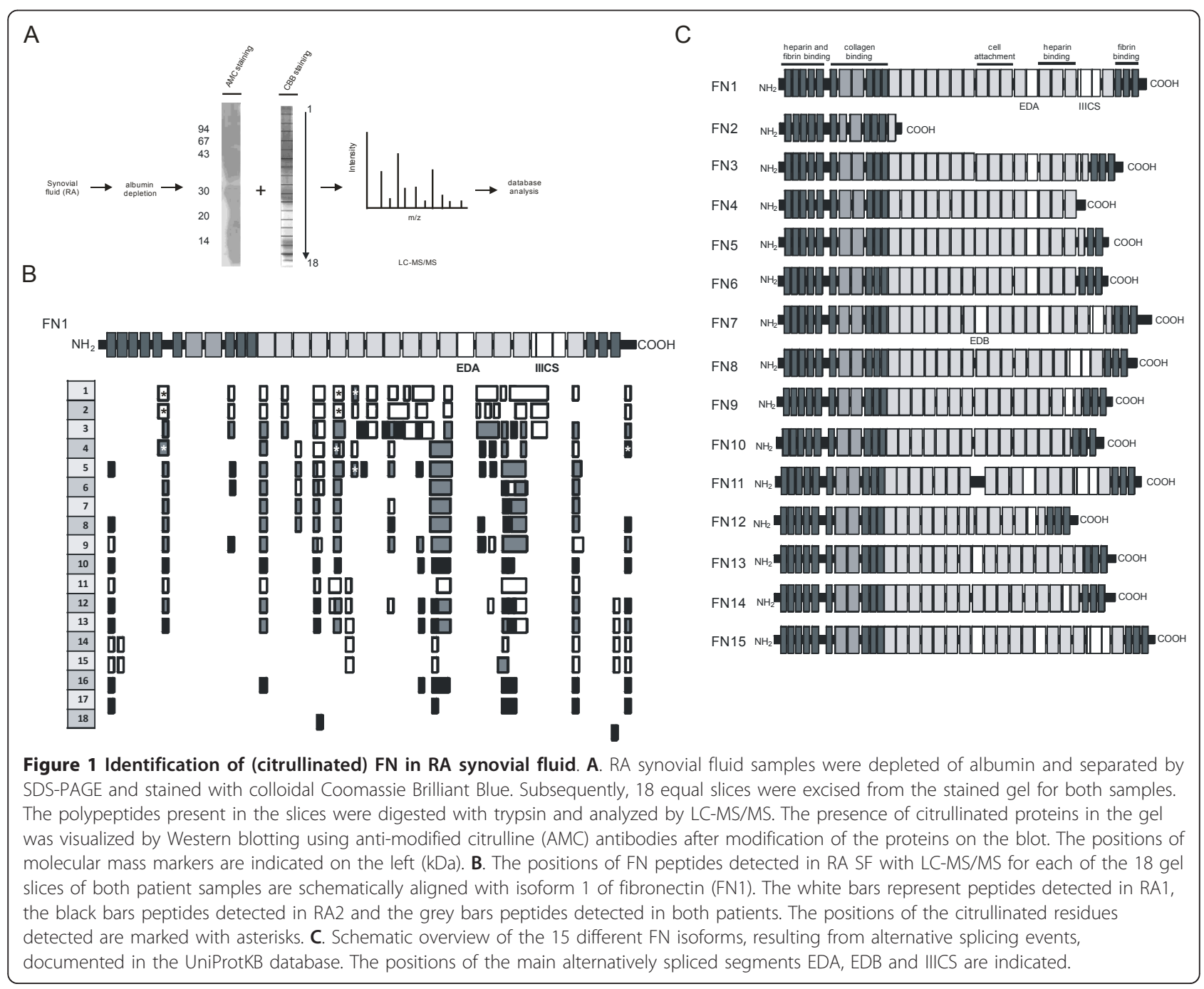


15 different isoforms exist (Figure 1C); the canonical isoform (FN1) comprises a polypeptide of 2,386 amino acids, in which three repeats can be discerned [52]. FNderived peptides that were found by these analyses covered most of the FN1 isoform, although for several regions no peptides were detected, which may at least in part be due to poor ionization efficiencies. For one of the alternatively spliced segments, extra domain A (EDA), no peptides were found in the data obtained, whereas several peptides demonstrating the absence of EDA were present. For IIICS, another alternatively spliced region, some peptide sequences were obtained with material from the high molecular weight fractions. Altogether, the mass spectrometry data covered $53 \%$ and $28 \%$ of the FN isoform 1 sequence for RA1 and RA2, respectively (Figure $1 \mathrm{~B}$ and Additional file 1: Figure S2).

A search for deiminated arginines identified four citrullinated FN regions containing five citrullinated residues, located at amino acid positions 241, 1035, 1036, 1162 and 2356 (Figure 1B). In RA1, four citrullinated residues were identified (positions 241, 1035, 1036 and 1162), whereas in the second patient (RA2) four citrullinated residues were identified (positions 241, 1035, 1162 and 2356) (Figure 1A and Table 1).

\section{Anti-citrullinated fibronectin peptide antibodies are specific for RA and are associated with the ACPA response}

To investigate the antigenicity of citrullinated FN, peptides comprising the citrullination sites identified were synthesized, as well as their arginine-containing counterparts (Table 1). A single peptide was synthesized for the flanking citrullination sites at positions 1035 and 1036, similar to the peptide identified in RA SF. The recognition of these peptides by antibodies in established RA patient sera $(n=23)$ was analyzed by ELISA. Two of these peptides, which contained either a citrulline at position 241 or at position 1162 (FN-Cit ${ }_{241}$ and FN$\mathrm{Cit}_{1162}$, respectively), were not recognized by RA sera. In contrast, the other two peptides (FN-Cit ${ }_{1035,1036}$ and FN-Cit 2356 ) were reactive with RA sera, and for both this reactivity appeared to be citrulline-dependent (Figure 2A-D). To substantiate these data and to obtain an indication of the frequency by which these peptides are recognized, sera from a second, larger cohort of 80 established RA patients were analyzed. Also these sera were found to be frequently reactive with the FN$\mathrm{Cit}_{1035,1036}$ and FN-Cit 2356 peptides (Figure 2E, F). Forty-three percent of these sera appeared to recognize FN-Cit ${ }_{1035,1036}$, whereas eight percent was reactive with FN-Cit ${ }_{2356}$. To analyze the disease-specificity of antibodies to these citrullinated FN peptides, sera from 31 multiple sclerosis (MS), 32 type 1 diabetes (T1D), 31 primary Sjőgren's syndrome (pSS), 31 systemic lupus erythematosus (SLE) and 29 tuberculosis (TB) patients, and from 32 healthy individuals, in parallel with 75 established RA sera, were analyzed by ELISA. The results showed that less than two percent of the control sera was reactive with $\mathrm{FN}-\mathrm{Cit}_{1035,1036}$, whereas one percent displayed reactivity with FN-Cit 2356 (Figure 3).

Recently, it was shown that RA patients can be divided into two subsets based upon the presence or absence of ACPA in their sera and the CCP2 test appeared to be very suitable to differentiate between these subsets [53]. The analysis of anti FN-Cit ${ }_{1035,1036}$ reactivity in 131 anti-CCP2-positive and 28 anti-CCP2negative RA sera (Figure 4) showed that the anti-citrullinated fibronectin antibodies were hardly present in antiCCP2-negative RA sera, corroborating the idea that these antibodies are part of the ACPA response in antiCCP2-positive RA patients. The combined analyses of the established RA sera resulted in a prevalence of 50 percent for the autoantibodies to peptide FN-Cit Fa35,1036 $_{10}$ (Table 2), LTVGLTXXGQPRQY (X represents citrulline), in CCP2-positive established RA sera $(n=82)$.

\section{Autoantibodies against citrullinated fibronectin peptide are present early in the disease}

Autoantibodies against CCP2 peptides have been demonstrated to be detectable very early in the disease. Moreover, their presence in pre-disease sera predicts the development of RA $[5,6,54]$. The diversification of the ACPA response was found to occur mainly in the pre-disease stage. To investigate whether autoantibodies against citrullinated FN are also detectable in the early stages of RA development, a number of sera from early arthritis (EAC) patients (CCP2negative, $n=23$; CCP2-positive, $n=24$ ) was analyzed. As observed before for the established RA sera, also the EAC sera reactive with the $\mathrm{FN}-\mathrm{Cit}_{1035,1036}$ peptide represented a subgroup of the anti-CCP2-positive patients (Figure 5A). To substantiate these data and to obtain an indication of the frequency by which the FN-Cit ${ }_{1035,1036}$ peptide was recognized, additional CCP2-positive early arthritis sera ( $n$ $=278$ ) were analyzed. Forty-five percent of these CCP2positive EAC sera appeared to be reactive with the citrullinated fibronectin peptide containing citrulline residues at positions 1035 and 1036 (Figure 5B and Table 2). Only a small fraction of these early arthritis sera (4\%) displayed some reactivity with the corresponding arginine-containing peptide (Figure 5B).

It is known that after disease onset ACPA isotype switching may occur [55]. To investigate isotype switching of antibodies to citrullinated FN, 23 anti-FN-Cit ${ }_{1035,1036-}$ positive sera for which both samples taken at baseline and approximately seven years after disease onset were available, were selected and analyzed in ELISA with isotypespecific (IgG, IgM and IgA) secondary antibody conjugates. At baseline $(t=0), 87 \%$ of the reactive sera 
A

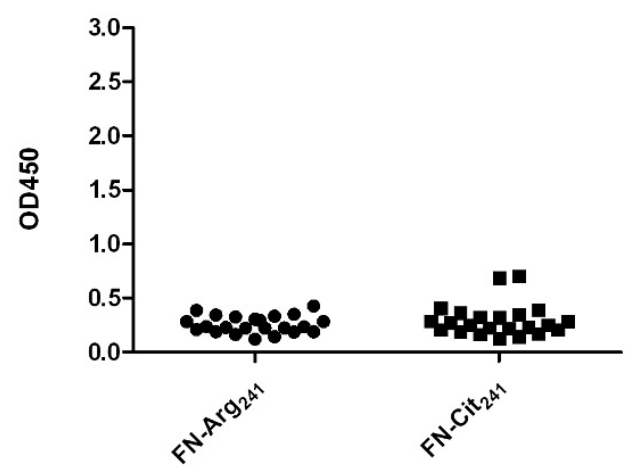

C

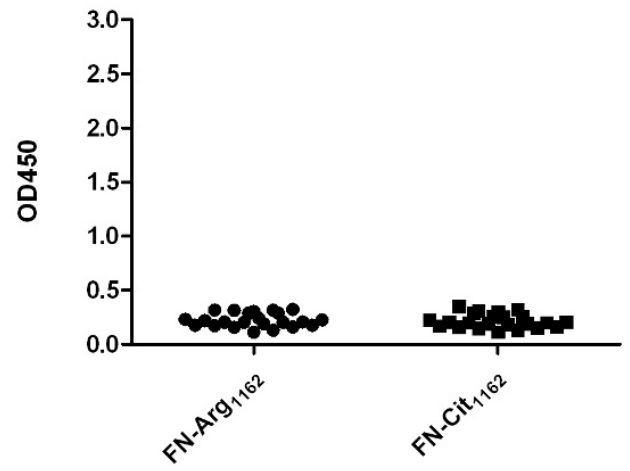

$\mathbf{E}$

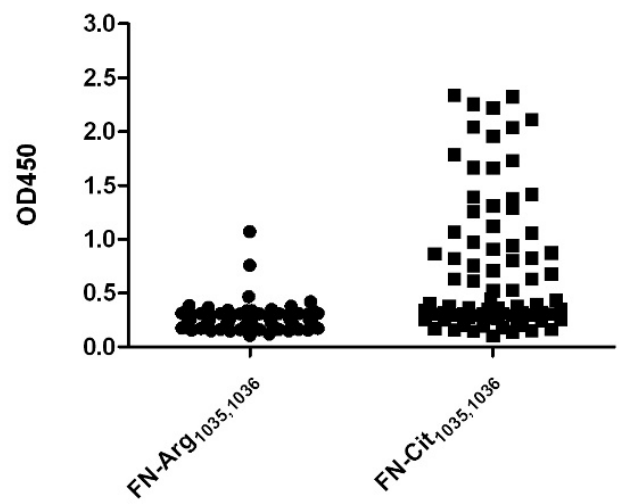

B

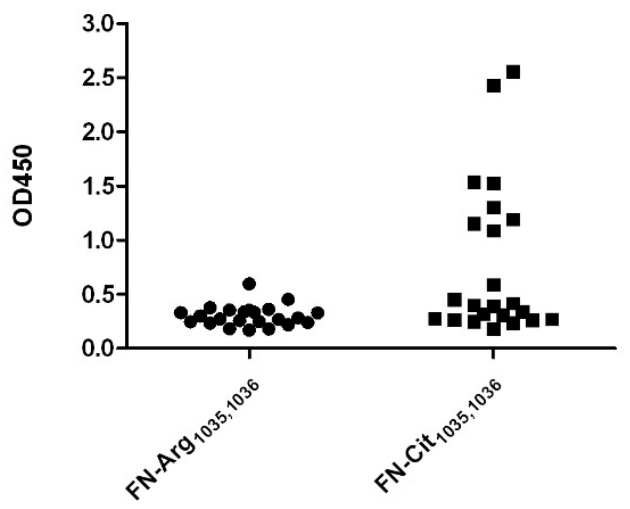

D

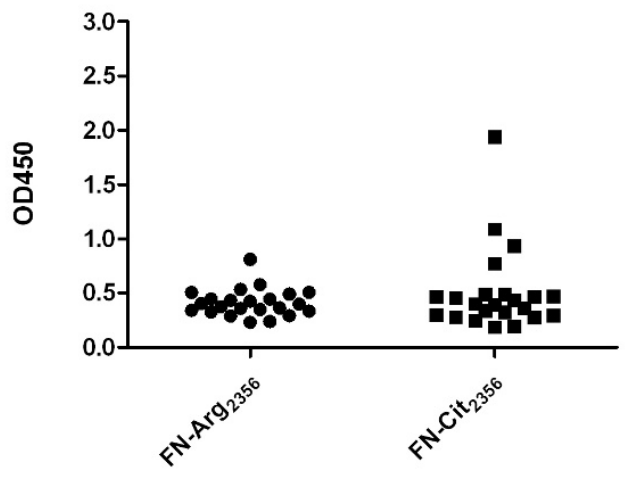

$\mathbf{F}$

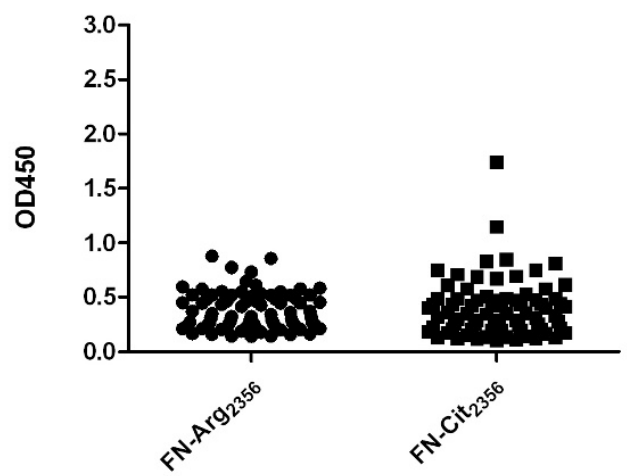

Figure 2 Recognition of citrullinated fibronectin peptides by RA sera. The four fibronectin peptide sets (A, FN-Arg/Cit 241 ; B, FN-Arg/ $\mathrm{Cit}_{1035,1036 ;} \mathbf{C}, \mathrm{FN}-\mathrm{Arg} / \mathrm{Cit}_{1162} ; \mathbf{D}$, FN-Arg/Cit ${ }_{2356}$ ) were analyzed by ELISA with 23 sera from established RA patients. Two peptide sets (E, FN-Arg/ $\mathrm{Cit}_{1035,1036 ;}$ F, FN-Arg/Cit 2356 ) were analyzed with a larger cohort obtained from established RA sera $(n=80)$. OD450 = optical density at $450 \mathrm{~nm}$. 


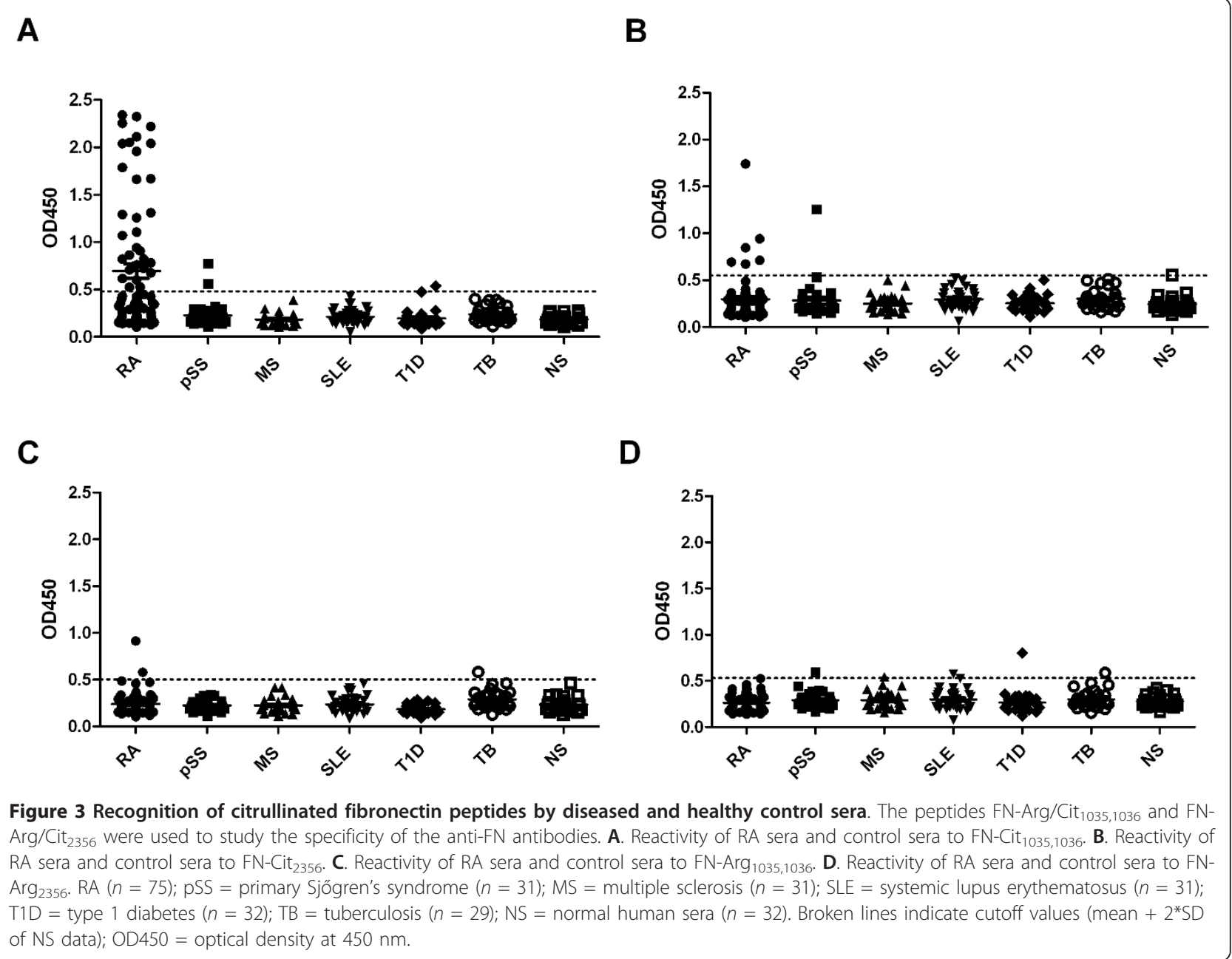

contained immunoglobulins of the IgG isotype (Figure $6 \mathrm{~A}$ ), whereas $13 \%$ contained IgM (Figure $6 \mathrm{C}$ ) and $4 \%$ contained IgA (Figure 6E) type reactivities. After a median follow-up time of seven years $(t=7)$ the frequency of IgG type antibodies to $\mathrm{FN}-\mathrm{Cit}_{1035,1036}$ was slightly decreased to $74 \%$ (Figure 6B). In these patients the frequency of IgM type anti-FN-Cit ${ }_{1035,1036}$ antibodies decreased to $4 \%$ (Figure 6D) In contrast, at this stage the frequency of IgA type antibodies to this citrullinated FN peptide increased to 13\% (Figure 6F). All IgM- and IgA-positive patients were also positive for IgG, whereas the simultaneous presence of IgM and IgA reactivities in the same patients was observed in one patient. Except for two patients, in which the IgG type anti-FN-Cit ${ }_{1035,1036}$ antibodies disappeared, the presence of these IgG antibodies did not markedly change in time (Figure 6G).

\section{Anti-citrullinated fibronectin peptide antibodies are associated with HLA SE alleles}

The HLA-DRB1*01, HLA-DRB1*04, HLA-DRB1*10 and $H L A-D R B 1 * 14$ alleles comprise the group of HLA SE alleles, which are associated with RA [56]. The reactivity to FN-Cit ${ }_{1035,1036}$ was compared with the HLA-DRB1 alleles of the 278 early arthritis patients. The results showed that the presence of HLA SE alleles is associated with the production of anti-citrullinated fibronectin antibodies, because patients carrying HLA SE alleles are more than two times more likely to have autoantibodies against citrullinated fibronectin $(\mathrm{OR}=2.11$; Table 3 and Additional file 1: Table S1). When addressing individual $H L A-D R B 1$ alleles, only HLA-DRB1\%04 (OR = 1.5), and $H L A-D R B 1 * 10(\mathrm{OR}=1.57)$ showed a weak to moderate association with the presence of anti-FN-Cit ${ }_{1035,1036}$ antibodies. Although a more pronounced association was observed with $H L A-D R B 1 * 08(\mathrm{OR}=2.45)$ and $H L A$ $D R B 1 * 16(\mathrm{OR}=2.43)$, these data should be interpreted with care because the carriage of these alleles is rare and the data are based on only a low number of patients. Interestingly, a negative association was observed between the presence of anti-citrullinated fibronectin antibodies and two additional $H L A-D R B 1$ alleles, $H L A-D R B 1 * 09$ and $H L A-D R B 1 * 11(\mathrm{OR}=0.19$ 


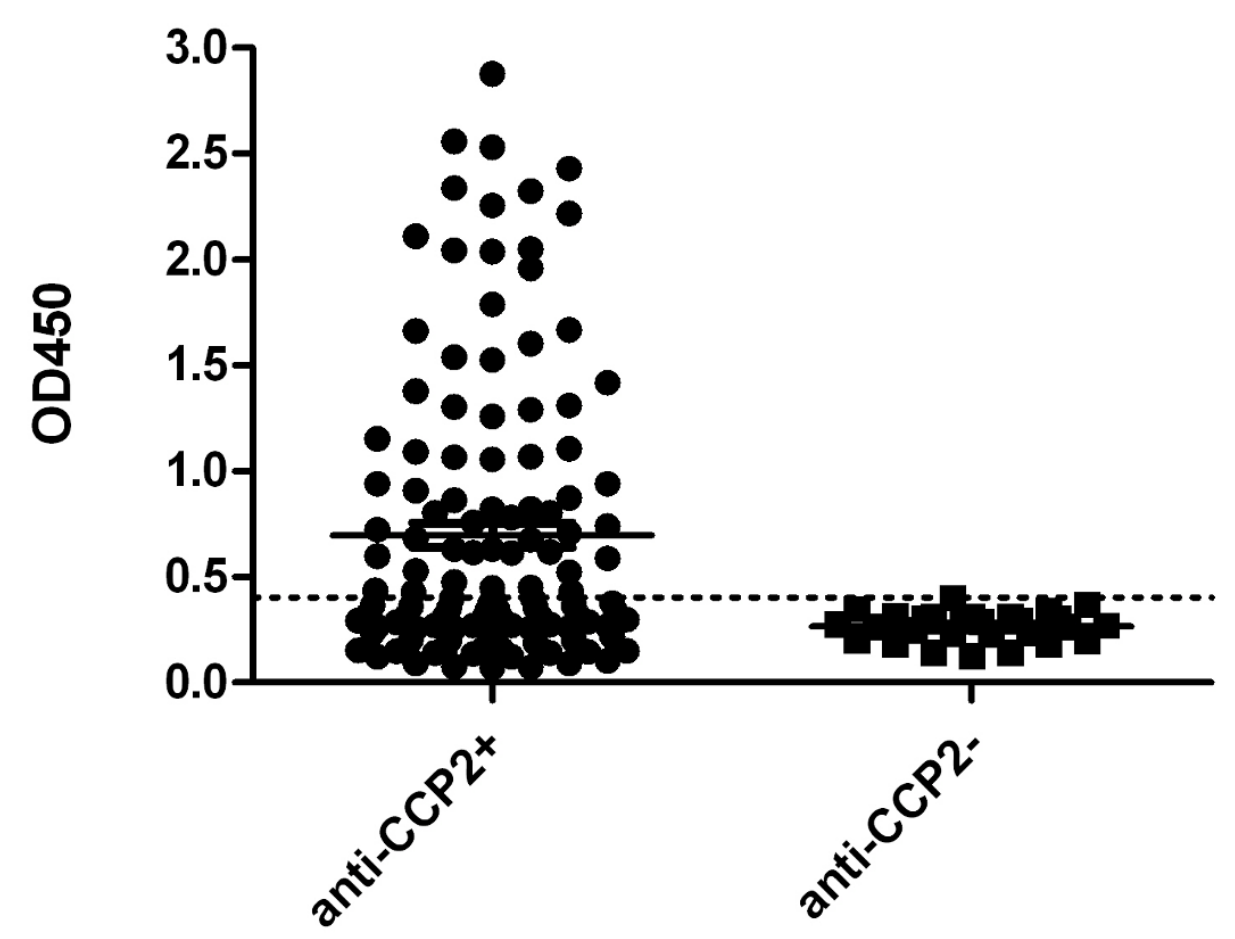

Figure 4 Anti-citrullinated fibronectin peptide antibodies in relation to anti-CCP2 positivity. The peptide set FN-Arg/Cit 1035,1036 was used to study the presence of anti-FN antibodies in anti-CCP2 positive $(n=138)$ and anti-CCP2 negative $(n=28)$ RA sera. The broken line indicates the cut-off value (mean $+2 * S D$ of data obtained with normal human control sera); OD450 = optical density at $450 \mathrm{~nm}$.

and $\mathrm{OR}=0.41$, respectively) (Additional file 1: Table S1).

In addition, the potential relationship of smoking with the production of anti-citrullinated fibronectin antibodies was assessed and a weak association was found (OR $=1.42$ ). We did not observe significant associations between the presence of anti-citrullinated fibronectin antibodies and clinical parameters, such as VAS score, HAQ score, Ritchie index or swollen joint count at baseline (data not shown).

\section{Discussion}

The analysis of citrullinated proteins in the synovial fluids of two rheumatoid arthritis patients revealed fibronectin as one of the multiply citrullinated proteins in both patients. Two of the four synthetic peptides that were derived from the citrullinated regions of FN appeared to be reactive with ACPA in the sera of RA patients. The most frequently targeted FN peptide, FN$\mathrm{Cit}_{1035,1036}$, which contains two adjacent citrullines, was recognized by $50 \%$ of established and $45 \%$ of early ACPA-positive RA patients. Like ACPA in general, antiFN-Cit ${ }_{1035,1036}$ antibodies appeared to be associated with HLA-DRB1 shared epitope alleles.

FN is a complex protein, characterized by the presence of three types of repeats in its polypeptide sequence, for which many isoforms resulting from alternative splicing events have been described (Figure 1C). The UniProtKB database provides details of 15 isoforms, with isoform 1 (FN1 in Figure 1C) as the canonical sequence. The overall sequence coverage of the mass spectrometry datasets relative to FN1 comprises 53\%

Table 2 Sensitivity and specificity of anti-citrullinated fibronectin antibodies.

\begin{tabular}{|c|c|c|c|c|}
\hline Patient group & $\mathrm{n}$ & anti-FN-Cit ${ }_{1035,1036}$ positive & sensitivity (\%) & specificity (\%) \\
\hline established $\mathrm{RA}^{\mathrm{a}}$ & 82 & 41 & 50.0 & \\
\hline early $R A^{a}$ & 278 & 124 & 44.6 & \\
\hline Controls & 186 & 3 & 1.6 & 98.4 \\
\hline non-RA & 154 & 3 & 1.9 & 98.1 \\
\hline Healthy & 32 & 0 & 0 & 100 \\
\hline
\end{tabular}

${ }^{a}$ Based upon CCP2-positive sera 
A

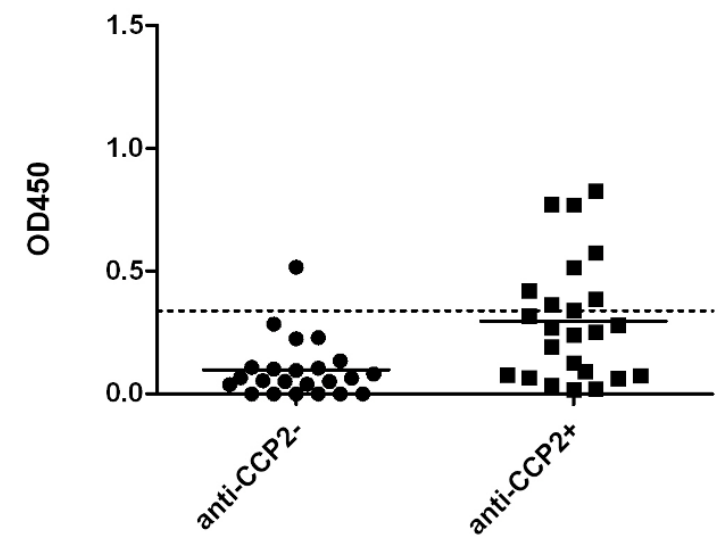

B

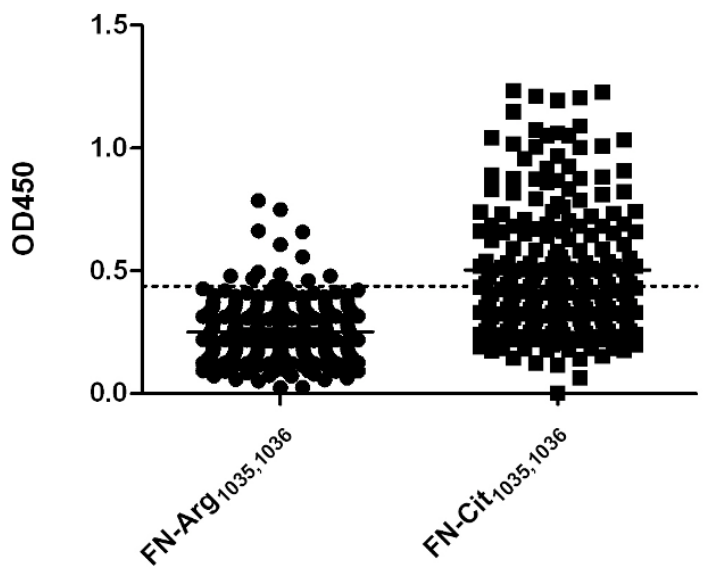

Figure 5 Anti-citrullinated fibronectin peptide antibodies in early arthritis patient sera. A. Sera from anti-CCP2-negative $(n=23)$ and antiCCP2-positive $(n=24)$ early arthritis patients were analyzed in the FN-Cit 1035,1036 ELISA. B. Sera from anti-CCP2-positive early arthritis patients $(n$ $=278$ ) were analyzed in the FN-Cit 1035,1036 ELISA. The broken line indicates the cut-off value (mean $+2 *$ SD of data obtained with normal human control sera); OD450 = optical density at $450 \mathrm{~nm}$.

and $28 \%$ for both synovial fluid samples, respectively. It is likely that multiple $\mathrm{FN}$ isoforms are expressed in the inflamed synovia of RA patients and our data do not allow drawing conclusions on their relative abundance. Three regions of FN are especially prone to alternative splicing; at the protein level these are termed extra domain A (EDA), extra domain B (EDB) and type III connecting segment (IIICS). Although peptides were found that match part of the IIICS sequence, no peptides were detected for EDA and EDB. Moreover, a few peptides provide evidence for the absence of EDA and EDB in the isoform(s) they originate from, because their sequences covered the regions immediately $\mathrm{N}$ - and $\mathrm{C}$ terminal from EDA or from EDB. The EDA domain, also designated EIIIA, has been implicated in inflammation, because it was shown to be involved in Toll-like receptor (TLR) 4 activation [57]. Although our data do not support the presence of EDA-containing FN isoforms in the synovial fluid of RA patients, it has been demonstrated previously that EDA-containing FN is produced in the RA synovium and is expressed abundantly in RA SF $[58,59]$. Moreover, recently Lefebvre and colleagues showed that EDA-containing FN stimulated leukotriene synthesis and neutrophil recruitment via TLR activation in a mouse model [60]. Although we could not detect any peptides in the EDA region, our data do not exclude the presence of EDA-containing FN isoforms in RA synovial fluid samples, because we have only analyzed a limited number of patients or because of technical limitations, such as ionization efficiencies.
The interpretation of the data is further complicated by the fact that $\mathrm{FN}$-derived peptides were found in material from many gel slices, which indicates a high heterogeneity of FN polypeptide lengths. It is likely that this is at least in part due to the presence of proteolytic enzymes in the synovial fluid from inflamed joints, which cleave the FN polypeptides in different fragments. It is known that during inflammation proteases are active in synovial fluid and can contribute to RA pathogenesis [61,62]. Indeed, the fragmentation of FN in inflammatory SF [63], as well as in cartilage of RA and osteoarthritis patients [64] has been reported previously.

Our analyses identified five citrullinated residues in FN from RA patient SF. Except for two adjacent citrullines, these residues are found in distant regions of the FN polypeptide chain. Our data do not provide information on the extent to which these residues are citrullinated in RA SF and it is likely that differences between patients exist. This is substantiated by the observation that in material from RA2 for the region containing the two adjacent citrullines only one of these two residues (1035) was found to be citrullinated, whereas both were citrullinated in RA1. Two other studies have previously reported the presence of citrullinated FN in SF and synovial tissue of RA patients $[41,43]$. However, these studies did not reveal the positions of the citrullinated residues. Our data do not exclude the possibility that FN is also citrullinated at other positions in RA SF, because material from only two patients was analyzed in detail and the sequence coverage was not more than 
A

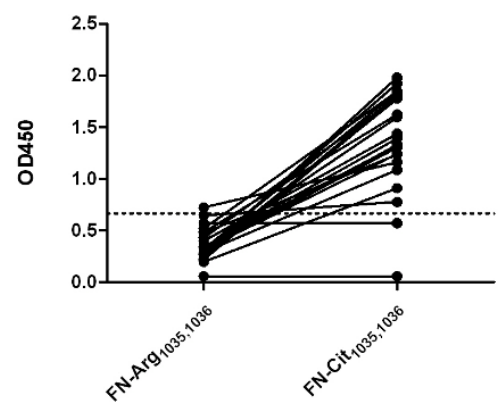

C

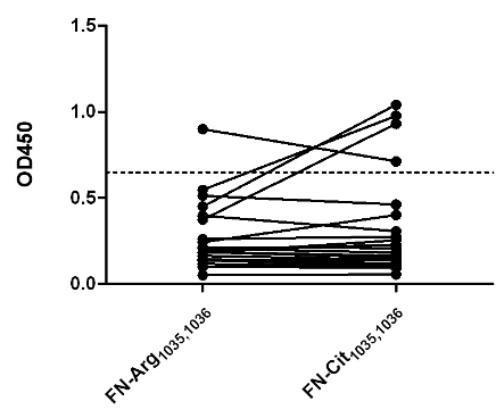

E

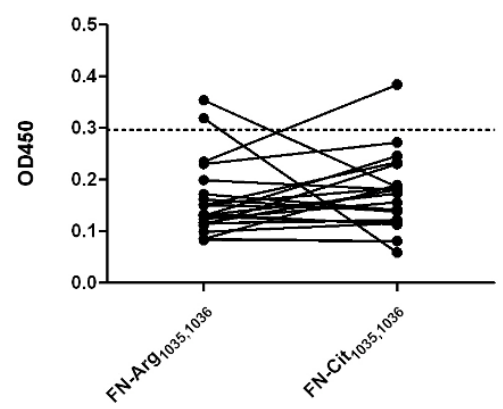

G

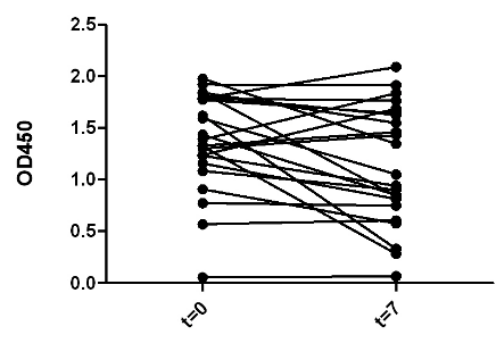

B

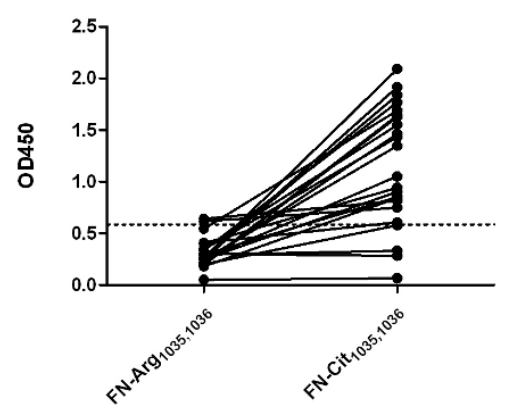

D

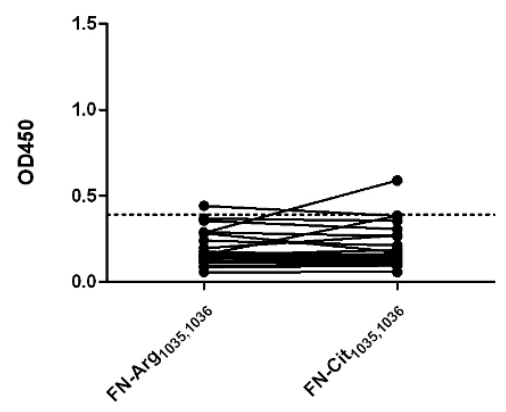

$\mathbf{F}$

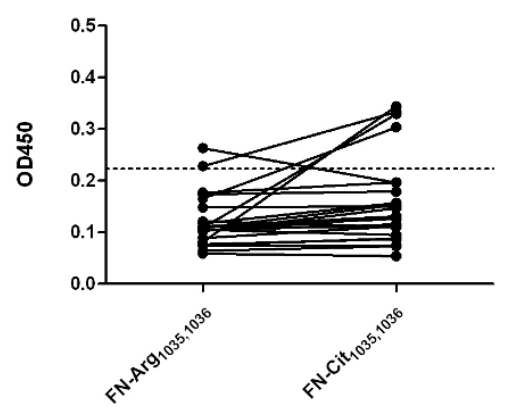

Figure 6 Anti-FN-Cit ${ }_{1035,1036}$ antibodies are predominantly of the IgG isotype. Sera from a subset of anti-FN-Cit 1035,1036 - positive early arthritis patients $(n=23)$ taken at baseline $(t=0)$ and after a median follow-up of seven years later $(t=7)$ were analyzed for different anti-FN$\mathrm{Cit}_{1035,1036}$ antibody isotypes in ELISA. A. IgG isotype reactivity at $\mathrm{t}=0$. B. IgG isotype reactivity at $\mathrm{t}=\mathbf{7}$. C. $\lg \mathrm{M}$ isotype reactivity at $\mathrm{t}=0$. $\mathbf{D}$. $\lg \mathrm{M}$ isotype reactivity at $t=7$. $\mathbf{E}$. IgA isotype reactivity at $t=0$. $\mathbf{F}$. IgA isotype reactivity at $t=7$. $\mathbf{G}$. Anti-FN-Cit $1035,1036 \lg$ reactivity at $t=0$ and $t=$ 7. The broken lines indicate the cut-off values determined by normal human control sera. 
Table 3 Association of anti-citrullinated fibronectin antibodies with smoking and SE alleles

\begin{tabular}{|c|c|c|c|c|}
\hline & & Anti-cit FN neg. (\%) ${ }^{d}$ & Anti-cit FN pos. $(\%)^{d}$ & OR $(95 \% \mathrm{Cl})$ \\
\hline \multirow[t]{2}{*}{ Smoking $^{a}$} & - & $63(46.7)$ & $40(38.1)$ & $1.42(0.85$ to 2.39$)$ \\
\hline & + & $72(53.3)$ & $65(61.9)$ & \\
\hline \multirow[t]{2}{*}{ HLA SE alleles ${ }^{b}$} & - & $39(26.5)$ & $57(14.6)$ & 2.11 (1.13 to 3.92$)$ \\
\hline & + & $108(73.5)$ & $213(85.4)$ & \\
\hline
\end{tabular}

${ }^{a}$ Based upon information obtained from 240 RA patients. ${ }^{b}$ Based upon information obtained from 270 RA patients. 95\% Cl, 95\% confidence interval; OR, odds ratio

53\%. Moreover, if citrullination enhances FN's susceptibility to proteolytic cleavage, citrullinated peptides may have escaped detection as a result of cleavages by endogenous proteases that cleave the polypeptide close to the citrullinated residue.

A synthetic peptide approach to investigate the recognition of citrullinated epitopes of FN by RA autoantibodies revealed that the major autoepitope is located in the region containing the two adjacent citrullines (amino acids 1035 and 1036). Only one of the other three citrullinated peptides was recognized by some RA sera. The fact that RA sera were only reactive with two of these peptides is consistent with the results of other studies showing that the amino acids flanking the citrulline residue contribute to the formation of auto-epitopes [1]. Several studies $[24,34,65]$ with synthetic citrullinated peptides (derived from vimentin, fibrinogen and $\alpha$-enolase) showed that not all peptides containing citrullinated residues are recognized by patient sera, indicating that not only the citrulline is important, but also the amino acids surrounding the citrullinated residue. However, it should be noted that the use of synthetic peptides in general does not allow the identification of reactivities with conformational and/or discontinuous epitopes. Therefore, our data do not exclude the possibility that the citrullinated residues identified are part of conformational epitopes and that autoantibodies to these epitopes may be present in RA patient sera. Although autoantibodies to FN have been detected in RA as well as SLE patients before [66,67], our data are the first to describe antibodies that target FN in a citrulline-dependent manner. The autoantibodies that can be detected with the FN-Cit ${ }_{1035,1036}$ peptide represent a subset of ACPA, which is substantiated by the lack of correlation between the levels of reactivity with CCP2 and with FN-Cit ${ }_{1035,1036}$ (Additional file 1: Figure S3). In total, 50\% of the (anti-CCP2-positive) established RA

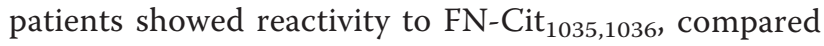
to two percent of the controls (non-RA and healthy individuals; Table 2).

The possibility existed that the anti-FN-Cit ${ }_{1035,1036}$ subset of ACPA overlapped with another subset that has been identified previously, as a result of epitope similarities. ACPA fine-specificity data were available for most of the EAC patient sera. The reactivity of these sera with FN-Cit ${ }_{1035,1036}$ was compared with their reactivity with two citrullinated peptides derived from vimentin (vimentin-1-16: STCitSVSSSSYCitCitMFGG; vimentin59-74: VYATCitSSAVCitLCitSSVP), two peptides derived from fibrinogen ( $\alpha$-fibrinogen-27-43: FLAEGGGVCitGPRVVERH; $\beta$-fibrinogen-36-52: NEEGFFSACitGHRPLDKK) and one peptide derived from $\alpha$-enolase ( $\alpha$-enolase-5-20: KIHACitEIFDSCitGNPTV) [39]. These analyses showed that most of the EAC sera recognized multiple citrullinated epitopes (Figure 7A). A large overlap of anti-FN-Cit ${ }_{1035,1036}$ with reactivities to any of the other peptides was observed, as might be expected from previous data $[26,68]$. However, some sera appeared to react exclusively with FN$\mathrm{Cit}_{1035,1036}$ and not with the other citrullinated epitopes (Figure 7B). These data are underscoring the large heterogeneity of the ACPA response in RA and indicate that the anti-FN-Cit ${ }_{1035,1036}$ antibodies are one of the most abundant ACPA subclasses that can be detected with synthetic peptides derived from citrullinated synovial proteins. Taken together, these data indicate that this citrullinated FN peptide may be used to investigate the fine-specificity of ACPA in more detail and may be complementary to other citrullinated molecules in ACPA profiling.

The anti-FN-Cit ${ }_{1035,1036}$ antibodies present in early arthritis patients appeared to be predominantly of the IgG isotype. Only a small percentage of sera was found to contain IgM or IgA type anti-FN-Cit ${ }_{1035,1036}$ antibodies. After a median follow-up of seven years, the IgG type reactivities were hardly changed, whereas the prevalence of IgM reactivity against $\mathrm{FN}-\mathrm{Cit}_{1035,1036}$ was decreased, and that of IgA was somewhat increased. Similar observations have been reported for samples from undifferentiated arthritis patients (who developed RA) taken either at baseline or after one year follow-up [36]. It remains an open question whether the anticitrullinated FN antibodies play a pathophysiological role. FN-containing immune complexes are likely to be formed in the inflamed joints of RA patients and this may occur already early during disease development. Further studies will be required to elucidate whether citrullinated FN is involved in the inflammatory process. 


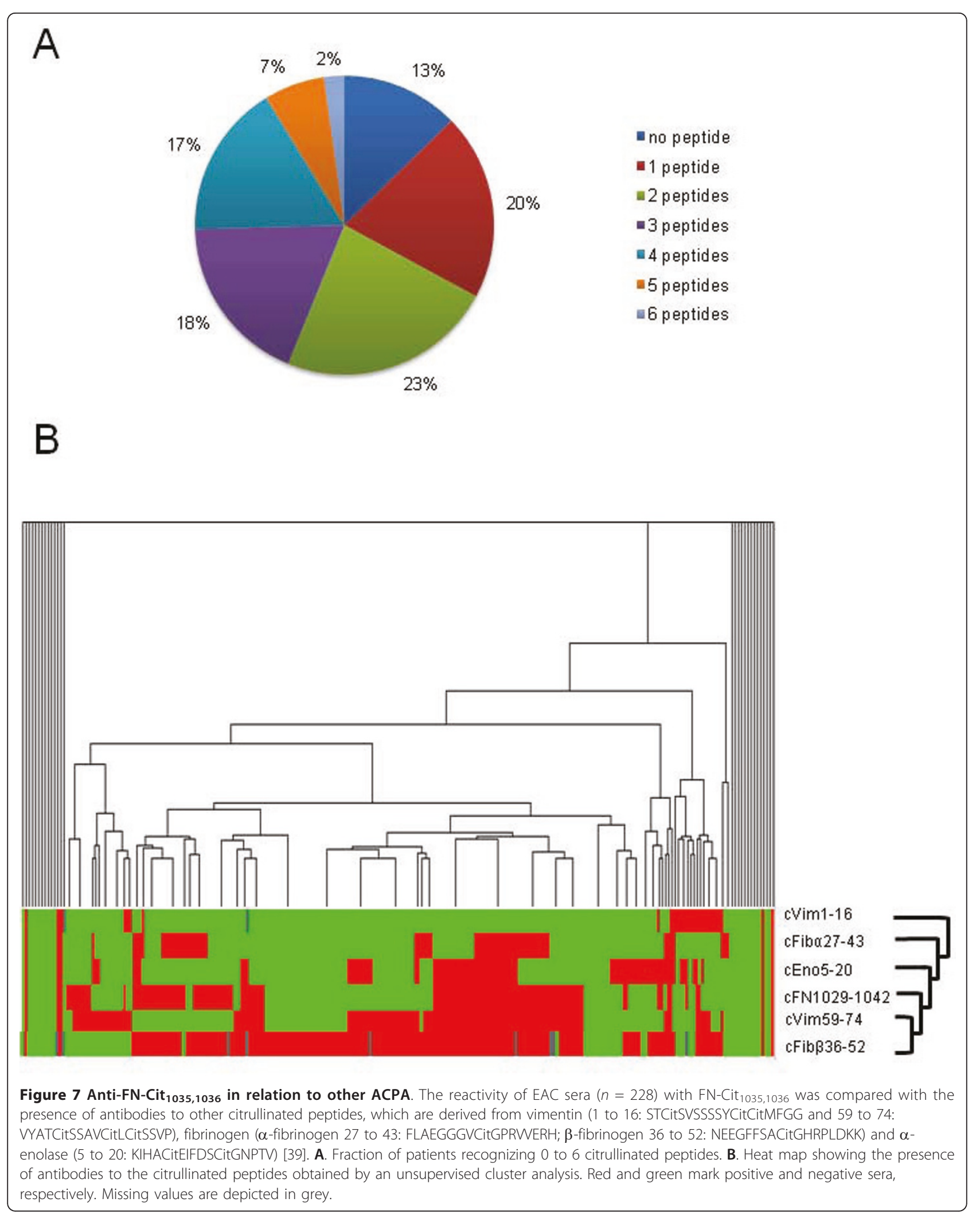


The presence of anti-citrullinated FN antibodies in the early arthritis patients was associated with HLA SE alleles $(\mathrm{OR}=2.11)$. Of the individual SE alleles, only $H L A-D R B 1 * 04$ and $H L A-D R B 1 * 10$ showed a weak association with the presence of anti-citrullinated FN peptide antibodies (Additional file 1: Table S1). Previously, Snir and co-workers demonstrated that antibodies against multiple citrullinated antigens (for example, vimentin, fibrinogen, $\alpha$-enolase and the C1-epitope of type II collagen) were associated with SE alleles, particularly with $H L A-D R B 1 * 04[26,69]$. Our data show a negative association of $H L A-D R B 1 * 09$ and $H L A-D R B 1 * 11$ with the presence of anti-citrullinated FN peptide antibodies $(\mathrm{OR}=0.19$ and $\mathrm{OR}=0.41$, respectively). This may be in agreement with the previously reported association of the HLA-DRB1*0901 haplotype with reduced levels of anti-CCP antibodies [70]. Paradoxically, $H L A$ $D R B 1 * 09$ has been reported previously to be associated with RA in Asian as well as Caucasian individuals [71,72]. In addition, it should be noted that, because ACPA-positive RA patients comprise a strong prevalence for SE-allelles, other $H L A-D R B 1$ alleles are less frequently present than SE-alleles and, therefore, might seem to be protective. As a consequence, the negative association observed with $H L A-D R B 1 * 09$ and HLADRB1*11 might also be the result of skewing [73].

We did not detect a significant association between clinical phenotype and the presence of anti-citrullinated fibronectin in ACPA-positive RA patients. Recently, Scherer and colleagues also observed no effect on radiographic joint damage in patients that were positive for several citrullinated epitopes [37]. Nevertheless, a weak correlation between the presence of autoantibodies against citrullinated FN and smoking, a risk factor for ACPA generation, particularly in individuals that carry the SE alleles [16,17], was observed.

\section{Conclusion}

Five citrullinated residues were identified in fibronectin isolated from the inflamed joints of RA patients. An epitope containing two adjacent citrullines at positions corresponding to residues 1035 and 1036 appeared to be most frequently recognized by RA sera. Our data not only show that antibodies against citrullinated FN are present in RA patients, but also demonstrate that the anti-FN antibodies represent a subgroup of anti-CCP2 antibodies and that they can already be detected very early in the disease. Moreover, anti-FN-Cit ${ }_{1035,1036}$ antibodies are associated primarily with HLA SE alleles.

\section{Additional material}

Additional file 1: Supplementary Table 1 and Supplementary

Figures 1 to 3 . Supplementary Table 1: Association of anti-citrullinated fibronectin antibodies and HLA-DRB1 alleles in anti-CCP2-positive early arthritis patients. Supplementary Figure 1: Overview of the handling of synovial fluid samples. Supplementary Figure 2: Fibronectin-derived peptides identified in the synovial fluid of RA patients. Supplementary Figure 3: Correlation between anti-CCP2 and anti-FN-Cit ${ }_{1035,1036}$ reactivities.

\section{Abbreviations}

ACPA: anti-citrullinated protein antibodies; AMC. anti-modified citrulline; BSA: bovine serum albumin; CBB: Coomassie Brilliant Blue; CCP: cyclic citrullinated peptide; Cl: coincidence interval; EAC: early arthritis clinic; EDA: extra domain A; EDB: extra domain B; FN: fibronectin; HAQ: health assessment questionnaire; HLA: human leukocyte antigen; IIICS: type III connecting segment; LC-MS/MS: liquid chromatography - tandem mass spectrometry; LTQ: linear trap quadrupole; MS: multiple sclerosis; NS: normal sera; OR: odds ratio; PAD: peptidylarginine deiminase; PBS: phosphate-buffered saline; PSS: primary Sjogren's syndrome; RA: rheumatoid arthritis; RF: rheumatoid factor; SE: shared epitope; SF: synovial fluid; SLE: systemic lupus erythematosus; T1D: type 1 diabetes; TB: tuberculosis; TLR: Toll-like receptor; TMB: 3,3',5,5'tetramethylbenzidine; VAS: visual analog scale

\section{Acknowledgements}

The authors would like to thank Prof. Dr. Borut Bozic (Department of Rheumatology, University Medical Centre, Ljubljana, Slovenia) for providing the synovial fluid samples and Prof. Dr. Walther van Venrooij for critically reading the manuscript. This work was supported in part by the Dutch Arthritis Association.

\section{Author details}

'Department of Biomolecular Chemistry, Institute for Molecules and Materials, Nijmegen Center for Molecular Life Sciences, Radboud University Nijmegen, P.O. Box 9101, 6500 HB Nijmegen, The Netherlands. ${ }^{2}$ Department of Rheumatology, Leiden University Medical Center, P.O. Box 9600, 2300 RC Leiden, The Netherlands. ${ }^{3}$ Department of Immunohematology and Blood Transfusion, Leiden University Medical Center, P.O. Box 9600, 2300 RC Leiden, The Netherlands.

\section{Authors' contributions}

$J \mathrm{VB}$ carried out the proteomic studies and part of the immunoassays, and participated in design of the study, interpretation of the data and drafting of the manuscript. AW participated in the analysis and interpretation of the data, performed the statistical analysis and contributed to the preparation of the manuscript. JS-V performed part of the immunoassays. JD participated in the design of the study, generated the synthetic peptides and participated in the preparation of the manuscript. RT participated in the design of the study, the interpretation of the data and the preparation of the manuscript. GP conceived of the study, participated in its design and coordination, contributed to the interpretation of the data and helped to draft the manuscript. All authors read and approved the final manuscript.

\section{Competing interests}

The authors declare that they have no competing interests.

Received: 24 August 2011 Revised: 5 January 2012

Accepted: 17 February 2012 Published: 17 February 2012

\section{References}

1. Gyorgy B, Toth E, Tarcsa E, Falus A, Buzas El: Citrullination: a posttranslational modification in health and disease. Int J Biochem Cell Biol 2006, 38:1662-1677.

2. Vossenaar ER, Smeets TJ, Kraan MC, Raats JM, van Venrooij WJ, Tak PP: The presence of citrullinated proteins is not specific for rheumatoid synovial tissue. Arthritis Rheum 2004, 50:3485-3494.

3. Schellekens GA, de Jong $B A$, van den Hoogen $F H$, van de Putte $L B$, van Venrooij WJ: Citrulline is an essential constituent of antigenic determinants recognized by rheumatoid arthritis-specific autoantibodies. J Clin Invest 1998, 101:273-281. 
4. van Venrooij WJ, van Beers JJ, Pruijn GJ: Anti-CCP antibody, a marker for the early detection of rheumatoid arthritis. Ann N Y Acad Sci 2008, 1143:268-285

5. Rantapaa-Dahlqvist S, de Jong BA, Berglin E, Hallmans G, Wadell G, Stenlund $H$, Sundin $U$, van Venrooij WJ: Antibodies against cyclic citrullinated peptide and $\lg A$ rheumatoid factor predict the development of rheumatoid arthritis. Arthritis Rheum 2003, 48:2741-2749.

6. van Gaalen FA, Linn-Rasker SP, van Venrooij WJ, de Jong BA, Breedveld FC, Verweij CL, Toes RE, Huizinga TW: Autoantibodies to cyclic citrullinated peptides predict progression to rheumatoid arthritis in patients with undifferentiated arthritis: a prospective cohort study. Arthritis Rheum 2004, 50:709-715.

7. van Venrooij WJ, Pruijn GJ: An important step towards completing the rheumatoid arthritis cycle. Arthritis Res Ther 2008, 10:117

8. Khani-Hanjani A, Lacaille D, Horne C, Chalmers A, Hoar DI, Balshaw R, Keown PA: Expression of QK/QR/RRRAA or DERAA motifs at the third hypervariable region of HLA-DRB1 and disease severity in rheumatoid arthritis. J Rheumatol 2002, 29:1358-1365.

9. van Gaalen FA, van Aken J, Huizinga TW, Schreuder GM, Breedveld FC, Zanelli E, van Venrooij WJ, Verweij CL, Toes RE, de Vries RR: Association between HLA class II genes and autoantibodies to cyclic citrullinated peptides (CCPs) influences the severity of rheumatoid arthritis. Arthritis Rheum 2004, 50:2113-2121.

10. Plenge RM, Seielstad M, Padyukov L, Lee AT, Remmers EF, Ding B, Liew A, Khalili H, Chandrasekaran A, Davies LR, Li W, Tan AK, Bonnard C, Ong RT, Thalamuthu A, Pettersson S, Liu C, Tian C, Chen WV, Carulli JP, Beckman EM, Altshuler D, Alfredsson L, Criswell LA, Amos Cl, Seldin MF, Kastner DL, Klareskog L, Gregersen PK: TRAF1-C5 as a risk locus for rheumatoid arthritis-a genomewide study. N Engl J Med 2007, 357:1199-1209.

11. Suzuki A, Yamada R, Chang X, Tokuhiro S, Sawada T, Suzuki M, Nagasaki M, Nakayama-Hamada M, Kawaida R, Ono M, Ohtsuki M, Furukawa H, Yoshino S, Yukioka M, Tohma S, Matsubara T, Wakitani S, Teshima R, Nishioka Y, Sekine A, lida A, Takahashi A, Tsunoda T, Nakamura Y, Yamamoto K: Functional haplotypes of PADI4, encoding citrullinating enzyme peptidylarginine deiminase 4, are associated with rheumatoid arthritis. Nat Genet 2003, 34:395-402.

12. Lee HS, Remmers EF, Le JM, Kastner DL, Bae SC, Gregersen PK: Association of STAT4 with rheumatoid arthritis in the Korean population. Mol Med 2007, 13:455-460.

13. Sigurdsson S, Padyukov L, Kurreeman FA, Liljedahl U, Wiman AC, Alfredsson L, Toes R, Ronnelid J, Klareskog L, Huizinga TW, Alm G, Syvanen $A C$, Ronnblom L: Association of a haplotype in the promoter region of the interferon regulatory factor 5 gene with rheumatoid arthritis. Arthritis Rheum 2007, 56:2202-2210.

14. Yanagawa T, Gomi K, Nakao El, Inada S: CTLA-4 gene polymorphism in Japanese patients with rheumatoid arthritis. J Rheumatol 2000, 27:2740-2742.

15. Begovich AB, Carlton VE, Honigberg LA, Schrodi SJ, Chokkalingam AP, Alexander HC, Ardlie KG, Huang Q, Smith AM, Spoerke JM, Conn MT, Chang M, Chang SY, Saiki RK, Catanese JJ, Leong DU, Garcia VE, McAllister LB, Jeffery DA, Lee AT, Batliwalla F, Remmers E, Criswell LA, Seldin MF, Kastner DL, Amos Cl, Sninsky JJ, Gregersen PK: A missense single-nucleotide polymorphism in a gene encoding a protein tyrosine phosphatase (PTPN22) is associated with rheumatoid arthritis. Am J Hum Genet 2004, 75:330-337.

16. Linn-Rasker SP, van der Helm-van Mil AH, van Gaalen FA, Kloppenburg M, de Vries RR, le Cessie S, Breedveld FC, Toes RE, Huizinga TW: Smoking is a risk factor for anti-CCP antibodies only in rheumatoid arthritis patients who carry HLA-DRB1 shared epitope alleles. Ann Rheum Dis 2006, 65:366-371.

17. Klareskog L, Stolt P, Lundberg K, Kallberg H, Bengtsson C, Grunewald J, Ronnelid J, Harris HE, Ulfgren AK, Rantapaa-Dahlqvist S, Eklund A, Padyukov L, Alfredsson L: A new model for an etiology of rheumatoid arthritis: smoking may trigger HLA-DR (shared epitope)-restricted immune reactions to autoantigens modified by citrullination. Arthritis Rheum 2006, 54:38-46.

18. Sverdrup B, Kallberg H, Bengtsson C, Lundberg I, Padyukov L, Alfredsson L, Klareskog L: Association between occupational exposure to mineral oil and rheumatoid arthritis: results from the Swedish EIRA case-control study. Arthritis Res Ther 2005, 7:R1296-R1303.
19. Rosell M, Wesley AM, Rydin K, Klareskog L, Alfredsson L: Dietary fish and fish oil and the risk of rheumatoid arthritis. Epidemiology 2009, 20:896-901.

20. Mikuls TR, Cerhan JR, Criswell LA, Merlino L, Mudano AS, Burma M, Folsom AR, Saag KG: Coffee, tea, and caffeine consumption and risk of rheumatoid arthritis: results from the lowa Women's Health Study. Arthritis Rheum 2002, 46:83-91.

21. Masson-Bessiere C, Sebbag M, Girbal-Neuhauser E, Nogueira L, Vincent C, Senshu T, Serre G: The major synovial targets of the rheumatoid arthritisspecific antifilaggrin autoantibodies are deiminated forms of the alphaand beta-chains of fibrin. J Immunol 2001, 166:4177-4184.

22. Vossenaar ER, Després N, Lapointe E, van der Heijden A, Lora M, Senshu T, van Venrooij WJ, Menard HA: Rheumatoid arthritis specific anti-Sa antibodies target citrullinated vimentin. Arthritis Res Ther 2004, 6: R142-R150.

23. Kinloch A, Tatzer V, Wait R, Peston D, Lundberg K, Donatien P, Moyes D, Taylor PC, Venables PJ: Identification of citrullinated alpha-enolase as a candidate autoantigen in rheumatoid arthritis. Arthritis ResTher 2005, 7: R1421-R1429.

24. Sebbag M, Moinard N, Auger I, Clavel C, Arnaud J, Nogueira L, Roudier J, Serre G: Epitopes of human fibrin recognized by the rheumatoid arthritis-specific autoantibodies to citrullinated proteins. Eur J Immunol 2006, 36:2250-2263.

25. Van Steendam K, Tilleman K, De Ceuleneer M, De Keyser F, Elewaut D, Deforce D: Citrullinated vimentin as an important antigen in immune complexes from synovial fluid of rheumatoid arthritis patients with antibodies against citrullinated proteins. Arthritis ResTher 2010, 12:R132.

26. Snir O, Widhe M, Hermansson M, von Spee C, Lindberg J, Hensen S, Lundberg K, Engström A, Venables PJ, Toes RE, Holmdahl R, Klareskog L, Malmström $V$ : Antibodies to several citrullinated antigens are enriched in the joints of rheumatoid arthritis patients. Arthritis Rheum 2010, 62:44-52.

27. Bizzaro N, Tonutti E, Tozzoli R, Villalta D: Analytical and diagnostic characteristics of 11 2nd- and 3rd-generation immunoenzymatic methods for the detection of antibodies to citrullinated proteins. Clin Chem 2007, 53:1527-1533.

28. Coenen D, Verschueren P, Westhovens R, Bossuyt X: Technical and diagnostic performance of 6 assays for the measurement of citrullinated protein/peptide antibodies in the diagnosis of rheumatoid arthritis. Clin Chem 2007, 53:498-504.

29. Mutlu N, Bicakcigil M, Tasan DA, Kaya A, Yavuz S, Ozden Al: Comparative performance analysis of 4 different anti-citrullinated protein assays in the diagnosis of rheumatoid arthritis. J Rheumatol 2009, 36:491-500.

30. Aletaha D, Neogi T, Silman AJ, Funovits J, Felson DT, Bingham CO III, Birnbaum NS, Burmester GR, Bykerk VP, Cohen MD, Combe B, Costenbader KH, Dougados M, Emery P, Ferraccioli G, Hazes JM, Hobbs K, Huizinga TW, Kavanaugh A, Kay J, Kvien TK, Laing T, Mease P, Menard HA, Moreland LW, Naden RL, Pincus T, Smolen JS, Stanislawska-Biernat E, Symmons D, et al: 2010 Rheumatoid arthritis classification criteria: an American College of Rheumatology/European League Against Rheumatism collaborative initiative. Arthritis Rheum 2010, 62:2569-2581.

31. Kinloch A, Lundberg K, Wait R, Wegner N, Lim NH, Zendman AJ, Saxne T, Malmstrom V, Venables PJ: Synovial fluid is a site of citrullination of autoantigens in inflammatory arthritis. Arthritis Rheum 2008, 58:2287-2295.

32. Matsuo K, Xiang Y, Nakamura H, Masuko K, Yudoh K, Noyori K, Nishioka K, Saito T, Kato T: Identification of novel citrullinated autoantigens of synovium in rheumatoid arthritis using a proteomic approach. Arthritis ResTher 2006, 8:R175.

33. Goeb V, Jouen F, Gilbert D, Le Loët X, Tron F, Vittecoq O: Diagnostic and prognostic usefulness of antibodies to citrullinated peptides. Joint Bone Spine 2009, 76:343-349.

34. Feitsma AL, van der Voort El, Franken KL, el Bannoudi H, Elferink BG, Drijfhout JW, Huizinga TW, de Vries RR, Toes RE, loan-Facsinay A: Identification of citrullinated vimentin peptides as T cell epitopes in HLA-DR4-positive patients with rheumatoid arthritis. Arthritis Rheum 2010, 62:117-125.

35. Ioan-Facsinay A, Willemze A, Robinson DB, Peschken CA, Markland J, van der Woude D, Elias B, Ménard HA, Newkirk M, Fritzler MJ, Toes RE, Huizinga TW, El-Gabalawy HS: Marked differences in fine specificity and isotype usage of the anti-citrullinated protein antibody in health and disease. Arthritis Rheum 2008, 58:3000-3008. 
36. van der Woude D, Syversen SW, van der Voort El, Verpoort KN, Goll GL, van der Linden MP, van der Helm-van Mil AH, van der Heijde DM, Huizinga TW, Kvien TK, Toes RE: The ACPA isotype profile reflects long-term radiographic progression in rheumatoid arthritis. Ann Rheum Dis 2010, 69:1110-1116

37. Scherer HU, van der Woude D, Willemze A, Trouw LA, Knevel R, Syversen SW, van der Linden MP, Lie B, Huizinga TW, van der Heijde DM, van der Helm-van Mil AH, Kvien TK, Toes RE: Distinct ACPA fine specificities, formed under the influence of HLA shared epitope alleles, have no effect on radiographic joint damage in rheumatoid arthritis. Ann Rheum Dis 2011, 70:1461-1464

38. Fisher BA, Plant D, Brode M, van Vollenhoven RF, Mathsson L, Symmons D, Lundberg K, Ronnelid J, Venables PJ: Antibodies to citrullinated alphaenolase peptide 1 and clinical and radiological outcomes in rheumatoid arthritis. Ann Rheum Dis 2011, 70:1095-1098.

39. Willemze A, Bohringer $S$, Knevel R, Levarht EN, Stoeken-Rijsbergen $G$, Houwing-Duistermaat JJ, van der Helm-van Mil AH, Huizinga TW, Toes RE, Trouw LA: The ACPA recognition profile and subgrouping of ACPApositive RA patients. Ann Rheum Dis 2012, 71:268-274.

40. van Beers JJBC, Zendman AJW, van Venrooij WJ, Pruijn GJM: Citrullination in the arthritic synovium; the citrullinome, the antibodies against citrullinated proteins and their connection with RA pathogenesis. In From Etiopathogenesis to the Prediction of Autoimmune Diseases: Relevance of Autoantibodies Report on the 8th Dresden Symposium on Autoantibodies September 12-15, 2007;Dresden. Volume 5. Edited by: Conrad K, Chan EKL, Fritzler MJ, Sack U, Shoenfeld Y, Wiik AS. Pabst Science Publishers: Lengerich, Germany; 2007:378-388, Autoantigens, Autoantibodies, Autoimmunity.

41. Chang X, Yamada R, Suzuki A, Kochi Y, Sawada T, Yamamoto K: Citrullination of fibronectin in rheumatoid arthritis synovial tissue. Rheumatology (Oxford) 2005, 44:1374-1382.

42. Potts JR, Campbell ID: Fibronectin structure and assembly. Curr Opin Cell Biol 1994, 6:648-655.

43. Tabushi Y, Nakanishi T, Takeuchi T, Nakajima M, Ueda K, Kotani T, Makino S, Shimizu A, Hanafusa T, Takubo T: Detection of citrullinated proteins in synovial fluids derived from patients with rheumatoid arthritis by proteomics-based analysis. Ann Clin Biochem 2008, 45:413-417.

44. Herbert KE, Coppock JS, Griffiths AM, Williams A, Robinson MW, Scott DL: Fibronectin and immune complexes in rheumatic diseases. Ann Rheum Dis 1987, 46:734-740

45. Scott DL, Delamere JP, Walton KW: The distribution of fibronectin in the pannus in rheumatoid arthritis. Br J Exp Pathol 1981, 62:362-368.

46. Xie D, Homandberg GA: Fibronectin fragments bind to and penetrate cartilage tissue resulting in proteinase expression and cartilage damage. Biochim Biophys Acta 1993, 1182:189-196.

47. Homandberg GA, Meyers R, Williams JM: Intraarticular injection of fibronectin fragments causes severe depletion of cartilage proteoglycans in vivo. J Rheumatol 1993, 20:1378-1382.

48. van Aken J, van Bilsen JH, Allaart CF, Huizinga TW, Breedveld FC: The Leiden Early Arthritis Clinic. Clin Exp Rheumatol 2003, 21:S100-S105.

49. Colantonio DA, Dunkinson C, Bovenkamp DE, Van Eyk JE: Effective removal of albumin from serum. Proteomics 2005, 5:3831-3835.

50. Hiemstra HS, Duinkerken G, Benckhuijsen WE, Amons R, de Vries RR, Roep BO, Drijfhout JW: The identification of CD4+ T cell epitopes with dedicated synthetic peptide libraries. Proc Natl Acad Sci USA 1997, 94:10313-10318.

51. Verpoort KN, Cheung K, loan-Facsinay A, van der Helm-van Mil AH, VriesBouwstra JK, Allaart CF, Drijfhout JW, de Vries RR, Breedveld FC, Huizinga TW, Pruijn GJ, Toes RE: Fine specificity of the anti-citrullinated protein antibody response is influenced by the shared epitope alleles. Arthritis Rheum 2007, 56:3949-3952.

52. White ES, Baralle FE, Muro AF: New insights into form and function of fibronectin splice variants. J Pathol 2008, 216:1-14.

53. van der Helm-van Mil AH, Verpoort KN, Breedveld FC, Toes RE, Huizinga TW: Antibodies to citrullinated proteins and differences in clinical progression of rheumatoid arthritis. Arthritis ResTher 2005, 7:R949-R958.

54. Schellekens GA, Visser H, de Jong BA, van den Hoogen FH, Hazes JM, Breedveld FC, van Venrooij WJ: The diagnostic properties of rheumatoid arthritis antibodies recognizing a cyclic citrullinated peptide. Arthritis Rheum 2000, 43:155-163.
55. Verpoort KN, Jol-van der Zijde CM, Papendrecht-van der Voort EA, loanFacsinay A, Drijfhout JW, van Tol MJ, Breedveld FC, Huizinga TW, Toes RE: Isotype distribution of anti-cyclic citrullinated peptide antibodies in undifferentiated arthritis and rheumatoid arthritis reflects an ongoing immune response. Arthritis Rheum 2006, 54:3799-3808.

56. Holoshitz J: The rheumatoid arthritis HLA-DRB1 shared epitope. Curr Opin Rheumatol 2010, 22:293-298.

57. Okamura Y, Watari M, Jerud ES, Young DW, Ishizaka ST, Rose J, Chow JC, Strauss JF III: The extra domain A of fibronectin activates Toll-like receptor 4. J Biol Chem 2001, 276:10229-10233.

58. Chevalier X, Claudepierre P, Groult N, Zardi L, Hornebeck W: Presence of ED-A containing fibronectin in human articular cartilage from patients with osteoarthritis and rheumatoid arthritis. J Rheumatol 1996, 23:1022-1030.

59. Hino K, Shiozawa S, Kuroki Y, Ishikawa H, Shiozawa K, Sekiguchi K, Hirano H, Sakashita E, Miyashita K, Chihara K: EDA-containing fibronectin is synthesized from rheumatoid synovial fibroblast-like cells. Arthritis Rheum 1995, 38:678-683.

60. Lefebvre JS, Levesque T, Picard S, Pare G, Gravel A, Flamand L, Borgeat P: Extra domain $A$ of fibronectin primes leukotriene biosynthesis and stimulates neutrophil migration through activation of Toll-like receptor 4. Arthritis Rheum 2011, 63:1527-1533.

61. Mantle D, Falkous G, Walker D: Quantification of protease activities in synovial fluid from rheumatoid and osteoarthritis cases: comparison with antioxidant and free radical damage markers. Clin Chim Acta 1999, 284:45-58.

62. Ronday HK, van der Laan WH, Tak PP, de Roos JA, Bank RA, TeKoppele JM, Froelich CJ, Hack CE, Hogendoorn PC, Breedveld FC, Verheijen JH: Human granzyme $B$ mediates cartilage proteoglycan degradation and is expressed at the invasive front of the synovium in rheumatoid arthritis. Rheumatology (Oxford) 2001, 40:55-61.

63. Barilla ML, Carsons SE: Fibronectin fragments and their role in inflammatory arthritis. Semin Arthritis Rheum 2000, 29:252-265.

64. Zack MD, Arner EC, Anglin CP, Alston JT, Malfait AM, Tortorella MD: Identification of fibronectin neoepitopes present in human osteoarthritic cartilage. Arthritis Rheum 2006, 54:2912-2922.

65. Lundberg K, Kinloch A, Fisher BA, Wegner N, Wait R, Charles P, Mikuls TR, Venables PJ: Antibodies to citrullinated alpha-enolase peptide 1 are specific for rheumatoid arthritis and cross-react with bacterial enolase. Arthritis Rheum 2008, 58:3009-3019.

66. Atta MS, Lim KL, Ala'deen DA, Powell RJ, Todd I: Investigation of the prevalence and clinical associations of antibodies to human fibronectin in systemic lupus erythematosus. Ann Rheum Dis 1995, 54:117-124.

67. Kim CW, Cho EH, Lee YJ, Kim YH, Hah YS, Kim DR: Disease-specific proteins from rheumatoid arthritis patients. J Korean Med Sci 2006, 21:478-484.

68. van der Woude D, Rantapaa-Dahlqvist S, loan-Facsinay A, Onnekink C, Schwarte CM, Verpoort KN, Drijfhout JW, Huizinga TW, Toes RE, Pruijn GJ: Epitope spreading of the anti-citrullinated protein antibody response occurs before disease onset and is associated with the disease course of early arthritis. Ann Rheum Dis 2010, 69:1554-1561.

69. Snir O, Widhe M, von Spee C, Lindberg J, Padyukov L, Lundberg K, Engstrom A, Venables PJ, Lundeberg J, Holmdahl R, Klareskog L, Malmstrom $\mathrm{V}$ : Multiple antibody reactivities to citrullinated antigens in sera from patients with rheumatoid arthritis: association with HLA-DRB1 alleles. Ann Rheum Dis 2009, 68:736-743.

70. Okada Y, Suzuki A, Yamada R, Kochi Y, Shimane K, Myouzen K, Kubo M, Nakamura Y, Yamamoto K: HLA-DRB1*0901 lowers anti-cyclic citrullinated peptide antibody levels in Japanese patients with rheumatoid arthritis. Ann Rheum Dis 2010, 69:1569-1570.

71. Lee HS, Irigoyen P, Kern M, Lee A, Batliwalla F, Khalili H, Wolfe F, Lum RF, Massarotti E, Weisman M, Bombardier C, Karlson EW, Criswell LA, Vlietinck R, Gregersen PK: Interaction between smoking, the shared epitope, and anti-cyclic citrullinated peptide: a mixed picture in three large North American rheumatoid arthritis cohorts. Arthritis Rheum 2007, 56:1745-1753.

72. Milicic A, Lee D, Brown MA, Darke C, Wordsworth BP: HLA-DR/DQ haplotype in rheumatoid arthritis: novel allelic associations in UK Caucasians. J Rheumatol 2002, 29:1821-1826.

73. van der Woude D, Lie BA, Lundstrom E, Balsa A, Feitsma AL, HouwingDuistermaat JJ, Verduijn W, Nordang GB, Alfredsson L, Klareskog L, PascualSalcedo D, Gonzalez-Gay MA, Lopez-Nevot MA, Valero F, Roep BO, 
Huizinga TW, Kvien TK, Martin J, Padyukov L, de Vries RR, Toes RE: Protection against anti-citrullinated protein antibody-positive rheumatoid arthritis is predominantly associated with HLA-DRB1*1301: a meta-analysis of HLA-DRB1 associations with anti-citrullinated protein antibody-positive and anti-citrullinated protein antibody-negative rheumatoid arthritis in four European populations. Arthritis Rheum 2010, 62:1236-1245

doi:10.1186/ar3744

Cite this article as: van Beers et al.: Anti-citrullinated fibronectin antibodies in rheumatoid arthritis are associated with human leukocyte antigen-DRB1 shared epitope alleles. Arthritis Research \& Therapy 2012 14: R35.

Submit your next manuscript to BioMed Central and take full advantage of:

- Convenient online submission

- Thorough peer review

- No space constraints or color figure charges

- Immediate publication on acceptance

- Inclusion in PubMed, CAS, Scopus and Google Scholar

- Research which is freely available for redistribution

Submit your manuscript at www.biomedcentral.com/submit 